\title{
縮合性高分子合成原料としての 芳香族カルボン酸
}

縮合性高分子の合成原料は官能基を 2 個以上含をこと が一般に必要であり，芳香族カルボン酸についても同㥞 のことがいえる。このため最も簡単な構造としては二塩 基性のフタル酸類があげられ，原料が豊富で安く，製造 法も比較的簡単であるなどの理由もあって，工業的に最 も重要な位置を占めている。これについで，ベンゼン系 の多塩基性酸が最近注目を集めている。未た官能基とし てカルボキシル基以外に水酸基を持ったるのはパルプ廃 液の利用といら面から研究されている。一塩基性酸であ る安息香酸もトルエンの利用という面からスニア法カプ ロラクタム, Dow 法石炭酸などが開発されているが，直 接の合成原料ではないのでここでは、京れないことにし

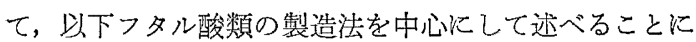
寸る。

\section{1. 無水フタル酸}

無水フタル酸の主な用途は塩化ビニル用可塑剤, アル キド樹脂，ポリェステル樹脂などであり，その製造法と しては従来からナフタリンの気相接触酸化法が用いられ てきている。しかし最近はナフタリンの供給不足によ り，安価な o-キシレンを原料とする方法が増加して拉 り,さらに液相空気酸化法の研究開発も進められている。

\section{1-1. ナフタリンの気相接触酸化法}

ナフタリンの気相接触酸化による無水フタル酸の製造 法は古くから発達して呿り，各社により細かい点で差は 岕るが，触媒にはすべて $\mathrm{V}_{2} \mathrm{O}_{5}$ 系が用いられている。従 来は固定床式のみでめったが，最近は流動床式方法が増 加している。

ナフタリンの酸化反応では, 発熱量が $416 \mathrm{kcal} / \mathrm{mol}$ ときわめて大きく，部分過熱によるフタル酸収率の低下 が最大の間題となっている。このため固定床式では多管 式反応器が用いられ，加熱媒体として水銀未た溶融塩 を用いて均一加熱を行ならようにしている。また原料に 対し $0.5 \sim 1.0 \mathrm{wt} \%$ の $\mathrm{SO}_{2}$ を混合して酸化すると過熱が 抑制され, $o$-キシンンの酸化では局部の最高温度を $35^{\circ} \mathrm{C}$

\footnotetext{
$*$ 東京大学工学部合成化学科・工博
}

山 下 順 三*

下げることに成功し，収率 8 12\% の上良がみられた $\mathrm{V}_{2} \mathrm{O}_{5}$ 系触媒の製造法については多くの特許があり，担 体としてアルミナ, 金属アルミニウム, 軽石, シリカな ぞが用いられている。 $\mathrm{K}_{2} \mathrm{SO}_{4}$ を添加すると収率が増加す るという報告もある。一般に無水フタル酸収率は原料ナ フタリンに対し 80 100 wt\% といわれる。

これと対し最近流動床式方法が発展してきたが，その 利点は部分過熱が防げるのでマレイン酸・ナフトキノン の副生が少なく, 精製が容易で製品純度も良いことで, また設備費が安く, 運転人員も少なくてよく, 触媒の再 生なぞのための運転休止が不要である。さらに固定床式 飞比し触媒単位重量あたりのナフタリン処理量は少ない が，空気消費量が少ないのは利点であるう。すなわちナ フタリンに対し約 11 倍量の空気を用い, 3 4 atm で反 応する。反応温度は $370 \pm 2^{\circ} \mathrm{C}$ という塽い範囲に制御す ることが可能であり, 触媒に付着した炭素はその場で容 易に燃焼除去しうるので, 特別の再生装置は不要で㐫る。 生産能力は流動化条件により制限されるので, 空気中の 酸素濃度を 24 ２7\% まで高くすると生産能力を $50 \%$ 程度上げることが可能である。無水フタル酸収率は $100 \mathrm{wt} \%$ に達するといわれる。工業化されている流動 床式方法としては Cyanamid 法, Sherwin-Williams 法, Badger 法, United Coke and Chemicals-Foster Wheeler 法などがある2)。

\section{1-2. その他の方法}

メチルナフタリン類を原料とする方法は無水フタル酸 収率が著しく低くなるので, 脱メチル化してナフタリン としてから酸化した方が有利である。フェナントレン， アントラセンの気相接触酸化でも無水フタル酸が得られ るが，収率は著しく低くなるる゙。

最近発展してきた ○ーキシレンを用いる気相接触酸化 法はナフタリンの場合とほぼ同様な方法を用いうるが, 一般的にナフタリン法より收率が劣る。しかし原料が豊 富で安価であり, 装置もナフタリン法と同じものが転用 できるので，しだいに增加の傾向にある。ただし流動床 式は採用できない。Scientific Design 社は最近 oーキシ 
レンより $90 \mathrm{wt} \%$ 程度の無水フタル酸を与克る新触媒を 開発したといわれ，注目される ${ }^{3)}$ 。㧧 0 -キシレン法で は $p$-キシレン, $m$-キシレンなどの不純物は $\mathrm{CO}_{2}$ と $\mathrm{H}_{2} \mathrm{O}$ に分解されるので, 原料 0 -キシレンの純度があまり問 題とならないことも利点と考兄られる。

ローキシレンを原料とする方法には, この他に液相酸化 法が開発されている。すなわち Catalytic Construction Co. は 0 -キシレンを液相空気酸化で 0 -トルイル酸とし， ついで硝酸酸化により無水フタル酸とするCowles 法を 開発したが，収率は $110 \mathrm{wt} \%$ に達するといわれ注目さ れている゙)。

\section{2. テレフタル酸}

テレフタル酸はエチレングリコールとのポリエステル 原料として最近著しく需要が増加した。その製造法はつ タル酸の場合に比しめんぞうであり, 種々の工夫がなさ れている。原料としても $p$-キシレンの他にトルエン・ 無水フタル酸・p-ジイソプロピルベンゼンなどを用いる あのがあり,きわめて種類が多い。

\section{2-1. p-キシレンを原料とする方法}

\section{2-1-1. 空気酸化法}

p-キシレンを $130 \sim 250^{\circ} \mathrm{C}$ の範囲で加圧下に液相空気 酸化する方法で, 酢酸などの溶媒を用いることが多く, $\mathrm{Co} \cdot \mathrm{Mn}$ 塩が触媒として用いられる。しかし通常の方法 では $p$-トルイル酸の段階で酸化が停止するので, 種々の 方法が工夫されている。

ふず 1 段酸化法では SD 法, MC 法, MD 法などと呼 ばれる Mid-Century Corp. が開発した方法がある5)。 酢酸を溶媒とし，Coをたは $\mathrm{Mn}$ 湓に $\mathrm{Br}$ を加穴たもの を螌媒として $170 \sim 200^{\circ} \mathrm{C}, 20 \mathrm{~atm}$ で空気酸化ずる $80 \%$ 以上の収率でテレフタル酸が得られる。 $\mathrm{Br}$ は $\mathrm{CoBr}_{2}, \mathrm{NH}_{4} \mathrm{Br}$ などの形で添加され，pートルイル酸 $\rightarrow$ テレフタル酸の酸化を促進する。日本では三井石油化 学, 丸善石油が採用して拈り,アメリカでは Amoco Chemical Corp. が混合キシレンの酸化に用いている。 この方法は高温で $\mathrm{Br}$, 酰酸などを処理するので, 反応装 置の腐食が問題であり，またテレフタル酸純度も悪いな ぞの欠点もあるが, 現在最も有力な方法とみられている。

この他の 1 段酸化法としては, Olin Mathieson Chemical Corp. Kよるメチルエチルケトン添加法が注 目される ${ }^{6)}$ 。すなわち酶酸溶液中でやや多量の $\mathrm{Co}(\mathrm{OAc})_{2}$ を触媒とし， $p$-キシンンを空気酸化するのであるが，こ の際 $\mathrm{MEK}$ を添加すると $\mathrm{Co}^{++} \rightarrow \mathrm{Co}^{+++}$の反応が促進さ れ，90 100 ${ }^{\circ} \mathrm{C}$, 常圧でテレフタル酸最高収率 $95 \%$ を与 えるといわれる。この方法の特徴は低温で空気酸化が行 ないうることで, 腐食の問題は少なくなると思われるが， 誘導期が長く, 触媒量も多いことが問題であろ5。

この他にも inhibitor の副生を抑制するために微量の
$\mathrm{Ni}, \mathrm{Cu}, \mathrm{Zn}, \mathrm{Sn}, \mathrm{Fe}$ を添加する方法7)，最初オゾンを用

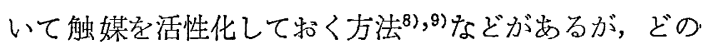
程度の利点があるか不明である。

2 段法としては Imhausen Werke, California Research Corp.が開発したエステル化法があり, Hercules Powder Co. で工業化されている2゙。すなわち $p$-キシレ ンを比較的ゆるやかな条件で液相空気酸化してまず $p$ トルイル酸とし, これをメチルエステルとしてからさら に空気酸化してテレフタル酸モノメチルとし, 最後にテ レフタル酸ジメチルとする方法である。第 1 段の酸化は $130 \sim 160^{\circ} \mathrm{C}$, 第 2 段の酸化は $180^{\circ} \mathrm{C}$ 程度で良く, 工程 数は多いが今日でも用いられている。この方法を改良し たものに第 2 段目の酸化觉 p-キシンン中で行ない,トル イル酸を同時に得ているもの ${ }^{10)}$, エステル化せずに別の 触媒を用いるもの ${ }^{11)}$, メタノール中で酸化して直接ジィ チルエステルを得るものなどがあるが，どの程度有利で あるかは判定しにくい。

\section{2-1-2. 硝酸酸化法}

Du Pont 社が工業的行なっている方法 ${ }^{12)}$ は $p$-キシ レンを $25 \sim 40 \%$ の硝酸で $200 \sim 230^{\circ} \mathrm{C}$ て酸化与る 1 段 法で、テレフタル酸収率は $90 \%$ 程度を示す。これに対 し $p$-キシレン $\rightarrow p$-トルイル酸の酸化を $130 \sim 150^{\circ} \mathrm{C}$ 程 度で行ない,ついで $200 \sim 230^{\circ} \mathrm{C}$ の高温でテレフタル酸 まて酸化する2段法るせる。

Richfield Oil Co. が開発中の方法は第 1 段を空気酸 化により行ない，第 2 段を硝酸酸化で行なうるので，硝 酸消費が約 $40 \%$ 節減できるといわれる ${ }^{13)}$ 。

硝酸酸化法は生成したテレフタル酸純度が惡く, 特に 1 段法はこの傾向が著しいのではないかと思われる。ま た酸化試剤を要することも空気酸化法に比し不利である う。副生する $\mathrm{NO}, \mathrm{NO}_{2}$ などをどの程度回収しうるかが 原価に相当響くものと考㝋られる。

\section{2-2. ヘンケル法}

フタル酸カリを $\mathrm{Cd}$ 触媒とともに $400^{\circ} \mathrm{C}$ 程度に加熱 異性化してテレフタル酸とする方法は, 初め Henkel \& Cie Kより開発され，BASF, Hercules Powder 社など でも工業化が検討されたが，結局日本の帝人，川崎化成 が世界で初めて工業化に成功している。

ヘンケル法では原料フタル酸純度が比較的恶くても良 く，なな得られるテレフタル酸の純度がきわわて良いの で, ジメチルエステルにして精製しないでそのままポリ エステル原料とすることが可能であるなど,利点がある。 しかし高価なカリ塩の回収に問題があり, $\mathrm{SO}_{2}$ 吹込みな ど種々の方法が特許となっているが, 詳細は不明である。 ヘンッル法はその後拡張されてイソフタル酸・ピロメ リット酸・メリット酸などのカリ塩からもテレフタル酸 が得られることがわかり, さらにナフタリン系, 複素環 系ジカルボン酸の合成にも適用しうる。特に安息香酸カ 
リを原料とするす方法は第 2 ヘンケル法として工業化が計 画さ礼ている。この場合 $\mathrm{CO}_{2} 20 \mathrm{~atm}$ 程度ではテレフタ ル酸の収率は $50 \%$ 以下で, 当モルのベンゼンを副生す る不均化反応と考古られていたが，その後 $\mathrm{CO}_{2} 1000 \mathrm{~atm}$ の高圧下ではテレフタル酸収率が最高 $91 \%$ にも達する ことがわかり，注目されている。原料安息香酸は安洒な トルエンの酸化により容易に得られることが利点であ る。な豍ベンゼンを原料とする同様の方法によるテレフ タル酸の合成法は, 収率が著しく低く, $\mathrm{CO}_{2}$ 圧力も 1000 $\sim 1500 \mathrm{~atm}$ と高く, 多量の脱水郕 $\mathrm{Al}_{4} \mathrm{C}_{3}$ を必要とする 点などから考光て工業化は不可能とみられる。またへン ケル法については最近東欧圈で研究が盛んである ${ }^{15)}$ 。

\section{2-3. その他の方法}

キシンン留分から p-キシレンの分離採取は相当めえ ぞうであり，また石油化学が大規模化していない国では p-キシレン価格は比較的高いので, これに代わる方法か゚ 研究されている。

まず N.V. Bataafsche Petroleum Maatschappij ${ }^{16)}$ は $p$-ジイソプロピルベンゼンの空気酸化によるテレフ タル酸の製造法を開発中で, $250 \mathrm{~kg} /$ 日 のパイロット試 験に入っている。ベンゼンをシリカーアルミナ系触媒で プロピレンと反応させると，条件を適当に選ぶことによ り o-体の生成を抑制しうる。 $p$-体と $m$-体の分離は蒸留 により容易に行ないうる。笑際にはベンゼンの直接ジア ルキル化は運転がめんどうなので, クメンとプロピレン を原料とする 2 段法が採用されている。一般にアルキル 化温度が低いほど $p$-体の収量が増し, 最大 $55 \%$ 飞達 する。p-体のみを得る目的で他の異性体を循環使用した 場合， $p$-体の収率は原料ベンゼン，プロピレンに対し $92.5 \mathrm{wt} \%$ で, この他に軽留分 $2.2 \mathrm{wt} \%$, 重留分 $5.5 \mathrm{wt} \%$ を副生し， $p$-体の純度は $99.5 \%$ を示す。

$p$-体の酸化法としては酶酸を溶媒とし, $\mathrm{Co}(\mathrm{OAc})_{2}$ と $\mathrm{Mn}(\mathrm{OAC})_{2}$ 苍触媒として用い, $120 \sim 150^{\circ} \mathrm{C}, 2 \sim 8 \mathrm{~atm}$ で の液相空気酸化法が用いられる。p-キシレン酸化の条件 よりずっとゆるやかな条件でテレフタル酸收率 $85 \%$ 程 度を与える点が利点といわれる。生成酸の純度はきわめ て良く、エステル化による精製はほとんど不要である。

Bergbau-Forschung GmbH はトルエンを原料とす る方法を閒発している ${ }^{17)}$ 。すなわち，トルエン 4 部とホ ルムアルデヒド 1 部の混合物を $33 \% \mathrm{HCl}$ により $70^{\circ} \mathrm{C}$ で反応させると純度 $98 \%$ のクロルメチルトルエンが得 られる。その o-体, p-体の比忟それぞれ 40\%, 就よび $60 \%$ である。酸化反応は $44 \% \mathrm{HNO}_{3}$ を用い, $91 \sim 95^{\circ} \mathrm{C}$, $1 \mathrm{hr}$ でまずトルイル酸まで酸化し，ついで $37 \% \mathrm{HNO}_{3}$ により $20 \mathrm{~atm}, 160^{\circ} \mathrm{C}, 1 \mathrm{hr}$ の反応でテレフタル酸にす る。テレフタル酸はこの際結晶として得られるので o体と容易に分離される。この方法は $200 \mathrm{~kg} /$ 日 のパイ ロット試験中でせる。テレフタル酸純度は $\mathrm{Cl} 0.1 \%, \mathrm{~N}$
$0.1 \%$ である。この方法の欠点は比較的高価なホルムア ルデヒドを原料に用い，交たクロルメチル化反応が著し く隃食性である点である。副生ずる $\mathrm{HCl}$ と $\mathrm{NO}_{2}$ の回 収も重要な点で,これによる製造贄への影響は大きいで あるう。

この他特殊な方法としては, p-ジクロルベンゼンとギ 酸メチルを $\mathrm{Na}_{2} \mathrm{CO}_{3}, \mathrm{Ni}(\mathrm{CO})_{4}$ 存在下に $\mathrm{CO} 200 \mathrm{~atm}$ 中で高温反応する方法があり, テレフタル酸掞よびエス テルが收率 $95 \%$ で得られる ${ }^{18)}$ 。特芘な酸化法としては キシンンの酸化に $\mathrm{NaOH}$ 水溶液, $\mathrm{ZnO}-\mathrm{MnO}_{2}$ 的媒を 用いた空気酸化法があり，また $p$-エチルアセトフェノ ンを $\mathrm{NaOCl}$ 水溶液て酸化してもテレフタル酸が得られ る19)。

この他 $p$-サイメン $p, p^{\prime}$-ジトリルメタン $p$-エチル トルエン, $p$-ジエチルベンゼン, $p$-ジアセチルベンゼン を原料とする方法が研究されているが，いずれす工業化 には㴗ど遠い段階にめる。

\section{3. イソフタル酸}

イソフタル酸は $m$-キシレンの酸化により得られる。 m-キシンンは $o$-キシンン, $p$-キシンンに比し, キシレ ン留分中の含有量が特に多い点, その将来性が特に注目 される。現在イソフタル酸はアメリカの Oronite 社が 22,700トン/年 の設備で製造しているが, Amoco Chemical 社の Joliet, Ill. 工場の混合キシレン酸化設備 (MD 法) では 27,000 トン/年 の混合フタル酸を製造しうるの で, 将来需要が増加してもイソフタル酸の供給は容易で あろう。イソフタル酸のアメリカに扩ける消費量は 1958 年にわずか 2,700トン/年 であったが，1960 年には 13,950 トン/年に増加し, 1965 年には 27,000 トン/年 に達するものと期待される。特に Du Pont 社がパイロ ット試驗中の HT1 (イソフタル酸またはテレフタル酸と pーまたは $m$ ーフェニレンジアミンの重合体) 打よび California Research Corp. の MXD6 (m-キシリレンジア ミンとアジピン酸の西合体）などポリアミド類への利用 が注目される。

m-キシレンよりイソフタル酸への酸化では, 前述の p-キシレンの酸化法がずべて適用できるすのと考えてょ い。

イソフタル酸の生産者である Oronite 社は非常に特 殊な酸化法を採用している20)。ずなわり，水拉よびアン モニアの存在下にイオウをたは多硫化アンモニウムなど を用いて, $315 \sim 360^{\circ} \mathrm{C}, 175 \sim 420 \mathrm{~atm}$ で $m$-キシレンを 酸化するもので, 水-キシレン比を高くするとイソフタル 酸収率は 90〜95\% に達するといわれている。この酸化 法は, もちろん他の芳香族炭化水索類の側鎖酸化に上る カルボン酸の製造に適用しらる。

このイオウ化合物を用いる酸化法は, その後 Toland 
による改良研究が続けられており，硫酸塩を用いるも

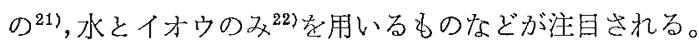

\section{4. その他の芳香族二塩基性カルボン酸}

ベンゼン系ジカルボン酸以外で現在高分子合成原料と して重要なるのはないが，今後どのようにとの需要が発 展するかは予測できない。

ホずナフタリン系カルボン酸では，2,6-ナフタリンジ カルボン酸が最も注目され，エチレングリコールとのポ リエステルは融点 $260^{\circ} \mathrm{C}$ で紡糸性があり, 工業化が検 討されている ${ }^{23)}$ 。その製造法としてはテレフタル酸と同 様，種々の方法が考兄られる。まず石油系ナフタリン製 造に伴い多量儿供給されるジメチルナフタリン留分中よ り，2,6-ジメチルナフタリンを分離し，その酸化によ。 て製造する方法がもる。酸化方法としては液相空気酸 化，硝酸酸化などが当然考えられるが，ナ゙フタリ核は ベンゼン核に比し不安定であるので，収率はあまり良く ない。最近 $\mathrm{S}-\mathrm{NH}_{3}-\mathrm{H}_{2} \mathrm{O}$ を用いて $275^{\circ} \mathrm{C}$ で酸化し, 収 率約 $60 \%$ に達したとい5報告がある ${ }^{24)}$ 。気相接触酸化， アルカリ水溶液酸素酸化などではベンゼン系カルボン酸 にまて酸化されてしまう。原料的にみても，2，6一体をジ メチルナフタリン留分より分離することは相当困難であ ろう。

も5一つの方法はナフタール酸, $\alpha-\beta$-ナフトエ酸定原 料とするヘンケル法による製造法である25)。ナフタール 酸はアセナフテンの接触空気酸化により容易に得られる し，ナフトエ酸は豊富なメチルナフタリンの酸化で得ら れる点, 注目される。酸化法ではイオウによる方法が良 く, 液相空気酸化法は収率が悪い。著者 ${ }^{26)}$ は $\mathrm{CO}_{2}$ 加 圧下, 約 $250^{\circ} \mathrm{C}$ で $\mathrm{Na}_{2} \mathrm{Cr}_{2} \mathrm{O}_{7}$ 水溶液による酸化を試夕, 収率 $90 \%$ 以上でナフトエ酸を得ることに成功した。こ の方法は高価な酸化剂を使う点が欠点であるが，副生す る $\mathrm{Cr}_{2} \mathrm{O}_{3}$ を $\mathrm{NaOH}$ とともに $300^{\circ} \mathrm{C}$ 以上で空気酸化し て $\mathrm{Na}_{2} \mathrm{Cr}_{2} \mathrm{O}_{7}$ を再生することが可能であるので, 興味深 い。特に反応が選択的で，メチル基のみが酸化され，製 品純度が良い点が利点である。

ビフェニル系カルボン酸ではジフェン酸が注目され る。これはフェナントレンの酸化により製造しうる。す なわち前記重ク口ム酸ソーダ水溶液酸化, 過酷酸酸化 ${ }^{27)}$, オン゙ン酸化 ${ }^{28)}$ な゙の方法がある。豊富なフェナントレン の利用法として一応興味深いが，ジフェン酸自身の用途 は末開拓でめる。

4,4'ービフェニルジカルボン酸はやはりポリェステル原 料になりらるが，その製造法としてジフェン酸のヘンケ ル法によるものが注目される。しかて著者らの実験では 収率があまり良くないので, 今後の研究に待つべきもの が多い。

\section{5. 多塩基性カルボン酸, その他}

1,2,4-ベンゼントリカルボン酸, すなわちトリメリッ ト酸はアルキド樹脂用として注目され，その塗料は速乾 性でかたい膜を与亲る。1958 年よりアメリカで用途開 発用に製造されている。原料には芳香族油中の $1,2,4-$ トリメチルベンゼン，与なわらプソイドクメンが用いら れ，MD 法空気酸化が適用される。

これと同じょうな用途が期待されるものとしては 1,2,4,5-ベンゼンテトラカルボン酸, すなわちピロメリ ット酸が女り，対応するテトラメチルベンゼン，すなわ らジュレンから製造される。以前は気相酸化法が採用さ れていたが，最近はすず空気酸化で 2,4,5-トリメチル 安息香酸とした後，硝酸酸化して製造する2段法が有利 とされている。

この他特殊な酸としては $p$-オキシ安息香酸, プロト カテキュ酸がある。前者は石炭酸の Kolbe-Schmidt 反 応により製造しうるが, むしろリグニンの水添分解によ り得られる $p$ クレゾールを原料とするるのが工業的に は重要であるう。この際通常の酸化ではベンゼン核が先 にこわれるので, アルカリ融解酸化, イオウ酸化など特 殊な方法を用いる必要がせるう。

プロトカテキュ酸はパルプ廃液より得られるワニリン より容易に製造しうる。これをエピクロルヒドリンと縮 合後ポリエステルとす机ば融点 $210^{\circ} \mathrm{C}$ の紡糸性のもの が得られる。ワニリンをどの程度安価に供給しうるかが 今後の問題となろう。

以上芳香族カルボン酸の製造法について述べたが，工 業的に重要なのは気相接触酸化, 液相空気酸化であり, 睄酸酸化, ヘンケル法, $\mathrm{NH}_{3}-\mathrm{S}$ 酸化などは特殊な方法と 考えられる。他の酸化剂を使万方法はその酸化剂の再生 が容易でしかも酸化が選択的で能率の良い場合にのみ発 展の可能性があろう。

最後に原稿を京とめるにめたり種々有益な示唆を与え られた東京大学工学部御園生晃教授に深謝し京す。

\section{文献}

1) USP $2,574,511 ; 2,574,512$ (1951)

2) M. Sittig: Petroleum Refiner, 41, No. 7, 119 (1962)

3) C. R. Kinney et al: Ind. Eng. Chem., 43, 2880 (1951)

4) Chem. Eng., 68, 53 (Aug. 7, 1961)

5) D. E. Burney et al: Petroleum Refiner, 38, No. 6, 186 (1959)

6) W. F. Brill: Ind. Eng. Chem., 52, 837 (1960)

7) Brit. P. 851,562 (1960)

8) A. S. Hay et al: J. Org. Chem., 25, 616 (1960)

9) Brit. P. $798,619(1958)$

(432 ページへつづく) 
オーブン法は $2 \sim 3^{\circ} \mathrm{C}$ の温度変化によって飞, 着色に敏感 に響くので，標準サンプルを試験のたびごとに入れてお く必要があり，Moorshead 24) のよ5に標準色列による 方法もあるが，箱者ら ${ }^{19}$ は，色相の変化を色差計によ。 て定量する方法を採用して敊り，一定の明度（たと光ば 70 以上)，色差（たとえば 30 以下）になるような範团を 求めて加工条件, 安定剂の配合を决めている。

以上，等安定性試験法のみにつき考察をしてみたが， 現状では，必ずしも临足な試駼法はないが，より加工条 件近い方法を用いる必要があり，そういった意味で， 筆者は，プラストグラフ法と色相の定量化は，旧来法よ り進步した方法だと考える。

\section{5. おわりに}

PVC 工業以今後 PVC 樹脂自体, 可塑剂, 安定剂, 滑 剂, その他充てん剂および加工方法の改良進歩ととるに さらに発展するであうう。PVC 樹脂自体は，すでに無 可塑化, 高熱安定性, 高軟化点のものなど特色のあるも のが開発されている。

安定剂も経験的探索から抜け出し, 先入感をすてて安 定化機構の確立を計り，それを基にして加工分野で本当 に要求されるものを開発して行かねばならない。そのた めには, 安定剤メーカーと加工メーカーが和互の極端な 秘密主義を反省し，技術面のことはできるだけ腹をわっ て話しあ5協力関係が必要であり, 安定剤の研究, 企業 に関係している筆者はこのことを痛感している。

今後の安定剤の発展方向としては, 籍者は one-package の促進（耐熱，透明；耐候扰よび加工性のバランス のとれた複合型式)，現在多用されている金属セッケン系 の改良 (プレートアウト性), 金属セッケンと有機スズ化 合物の長所を兼備した有機金属化合物の発展を予想し, さらに PVC と安定剂との共重合樹脂の開発も夢ではな いと考光る。

\section{文献}

1) 松田種光：高分子, 11, 455 (1962)

2) W.S.Penn: Rubber and Plastics Weekly, 141, $8 \sim 12(1961)$

3) A. H. Frye, R. W. Horst : J. Polymer Sci., 40. 419 (1959)

4）長富力雄, 佐伯康治：工化, 65, 393 (1962)

5) E. J. Arlman: J. Polymer Sci., 42, 543 (1954)

6) A. Rieche, A. Grimm, H. Müche: Kunststoffe, 52, 265 (1962)

7）長富力焳, 佐伯康治：工化, 65, 999 (1962)

8) 三宅守治：化学工業, 13, 985 (1962)

9) C. H. Fuchsman: S. P. E.J. 15, 787 (1959)

10) 井本 稔: 化学, 14, 735 (1959)

11) A. H. Frye, R.W. Horst : J. Polymer Sci., 45, $1(1960)$

12）佐倉武久, 輿石 保：日本化学会 13 年会講演 (1960)

13) 森川 洸：PVC 討論会講演 (1959)

14) G. M. Dyson et al: Plastics, 124 28 (1961)

15) W. Jashing: Kunststoffe, 52, 458 (1962)

16) A. Rieche, A.Grimm, H. Müche: Kunststoffe, 52, 398 (1962)

17) Y. Koga, R. Matuura: "Department of Chemisty of Science", Kyūsyū University Ser C., 4, No. 1 (1961)

18）木下洋一： ゴム協誌投稿中

19）营谷 功, 山越康雄, 木下洋一：PVC 討論会講演 (1962)：ゴム協誌投稿中

20) 斎藤誠三：化学工業. 13, 997 (1962)

21）木下洋一，村岡賢介： PVC 傠論会講演 (1962), 工化投稿中

22) O. R. Klimmer, I. U. Nebel: ArzneimittelForschung, 10, 44 (1960)

23）木下洋一, 山越康雄, 菅谷 功: ت゙ム協誌, 35 , $346(1962)$

24) T.C. Moorshead: Plastics, (Aug., 1957)
（山下順三著「縮合性高分子合成原料 としての芳香族 カルボン酸」の 441 ページよりのつづき)

10) Ger. P. 1,091,556 (1960)

11) Brit P. 857,098 (1960)

12) E. B. Bengtsson: Acta. Chem. Scand., 7, 774 (1953)

13) Brit. P. $846,442(1960)$

14）同前：有合協誌， $19 ， 570$ (1961); 小方：染料と 薬品, 6, 373 (1961)

15) Czech. P. 96,503; 97,205 (1960); Pol. P. 43,055 (1960)

16) J. P. Fortuin et al: Petroleum Refiner, 38, No. 6, 189 (1959)

17) Chem. Eng., 67, 76 (Jul. 11, 1960)

18) Ger. P. 1,074,028 (1960)

19) D. D. Neiswender, Jr. et al: J. Am. Chem.
Soc., 82, 2876 (1960)

20) W. G. Toland, Jr. et al: J. Am. Chem. Soc., 80, 5423 (1958)

21) W. G. Toland: J. Am. Chem. Soc., 82, 1911 (1960)

22) W. G. Toland: J. Org. Chem., 26, 2929 (1961)

23) Chem. Eng., 68, 122 (Apr. 17, 1961)

24) D. Klamann, U. Krämer: Erdöl und Kohle, 15, 438 (1962)

25）山下ら：有合協誌，20, 501 (1962)

26) 山下ら：有合協誌, 20, 277 (1962)

27) W. F. O'Connor et al: Ind. Eng. Chem., 45, 277 (1953)

28) W. F. O'Connor et al: Ind. Eng. Chem., 49, 1701 (1957) 